\title{
KANDYAN LAW AND BRITISH COLONIAL LAW: A CON- FLICT OF TRADITION AND MODERNITY - AN EARLY STAGE OF COLONIAL DEVELOPMENT IN SRI LANKA
}

\author{
By M. L. MARASINGHE
}

The Proclamation of 2nd March, 1815, known as the Kandyan Convention ${ }^{\mathbf{1}}$; declared and decreed:

"That the Rajah Sri Wickreme Rajah Sinha by the habitual violation of the chief and most sacred duties of a Sovereign, has forfeited all claims to that title of the powers annexed to the same, and is declared fallen and deposed from the office of King ... ${ }^{2}$ The Dominion of the Kandy Provinces is vested in the sovereign of the British Empire, and to be exercised through the Governors or Lieut-Governors of Ceylon for the time being and their accredited Agents, Saving to the Adigars, Dissaves, Mohattales, Corals, Vidhaans and all other chief and subordinate Native Headmen, carefully appointed by authority of the British Government, the rights and privileges and powers of their respective offices ...."

These Articles ${ }^{4}$ of the Convention effectively vested in the British Crown the Sovereignty of the Kandyan Kingdom. Article 4 further ordained that, "to all classes of the people the safety of their persons and property, with their Civil Rights and immunities, according to the laws, institutions and customs established and in force amongst them" were guaranteed. Under this Clause in Article 4, the British Administration inherited an entire legal system - which will be referred to in this paper as Kandyan Law - with very different and distinct societal underpinnings from those upon which the English Common Law traditions were founded. The British Administration in addition was committed to implement that system under a binding obligation ${ }^{5}$. Under Article 8 of the Convention, the British Administration undertook "the administration of Civil and Criminal Justice and police over the Kandyan inhabitants ... according to established forms". Under the same Article, the British Government reserved unto themselves grievances and reform of abuses in all instances whatever, whether particular or general, where such interpositions shall become necessary"'6. As a means of avoiding the full implications of this obligation, the Convention by Articles 6 and 7, excluded:

"Every species of bodily torture, and mutilation of limb, member or organ", and excluded the power to carry out sentences of death passed against any inhabitant "except

\footnotetext{
1 Although the Maritime Provinces of the Island of Ceylon (now the Republic of Sri Lanka) were occupied successively by the Portuguese, Dutch and the British between 1505 and 1815 A.D., the Central Kingdom of the Island - the Kandyan Kingdom - remained independent and sovereign throughout this period. The Kandyan Convention marks the legitimate handing over of the Kandyan Kingdom to the British. While the legality of the British claim to rule the Maritime Provinces could be founded upon a right of conquest, the legitimacy of the British rule over the Kandyan Kingdom is based on the Kandyan Convention. See: Vimalananda (T), The State and Religion in Ceylon Since 1815, M. D. Gunasena \& Co. Colombo, 1970, pp. 201-204 (Kandyan Convention). Also Mendis (U.L.B.) The Advent of the British to Ceylon, 1762-1803, Tisara, Colombo, 1971, Chap. Vl.

2 The Kandyan Convention, Article 2.

3 The Kandyan Convention, Article 4.

4 See footnotes 2 and 3.

5 Articles 4 and 8 are both implicit and explicit in this matter.

6 This catch-all clause was used by the British administration in Ceylon to reform the police powers and procedures in a way that the distinction between such powers and procedures as exercised between the Maritime Provinces which formed the Kandyan Kingdom became non-existent.

7 Article 6.
} 
by the written warrant of the British Governor or Lieut-Governor for the time being"8. Under these two provisions of the Convention the British Government excluded the imposition

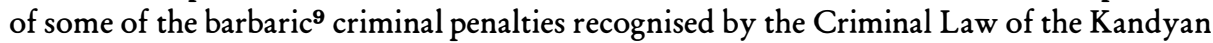
Kingdom. Aside from excluding these criminal penalties, the obligation undertaken by the British government under the Convention was extensive. The obligation to maintain the administration of the Kandyan personal law and to do justice according to the laws and customs of the Kandyan Kingdom, atleast in civil matters, was a total one. By Article 5 of the Convention the British Government accepted the further obligation to recognise that:

"The Religion of Boodhoo (i.e. Buddhism) professed by the chiefs and inhabitants of these provinces is declared inviolable, and its Rites, Ministers (i.e. Priests) and places of worship are to be maintained and protected."

This caused a fundamental conflict with the British monarch's role as the "defender of the (Church of England) faith". The totality of the obligations ${ }^{10}$ assumed by the British Administration caused some implemental problems. These problems could be traced easily to the different social goals persued by the two legal systems - the Kandyan and the English. The former was set within a traditional framework married to a set of traditional, social, cultural and religious values. It was non-evolutionary, static and therefore, incapable of growth or change. The English Common Law, on the other hand had evolved through centuries. It had absorbed elements from varying sources. Aside from the customary laws of the AngloSaxons, it had received contributions from such diverse socio-religious sources as the Greek and the Roman Laws as adapted by European legal systems on the one hand and the Canon Law on the other. Placed within a particular timeframe the English law was not only modern but was also constantly evolving. The position of the Sovereign within the framework of the new arrangement caused some considerable problems. Under the Kandyan Constitutional Laws, the King was the head of the Buddhist "church". There being no precise counterpart of The Pope of the Church of Rome or The Archbishop of Canterbury of the Church of England, the King of Kandy was regarded as the Supreme authority both on doctrinal and disciplinary matters connected with the Buddhist "church"11. The accommodation of these attributes within the total concept of the British Sovereign as the head of the Church of England, raised some unconventional problems ${ }^{12}$. When the Kandyan law is set within the framework of the English Common Law, a classic conflict of "tradition and modernity" emerge, raising the broader issue of development. The theme of this paper is development. The purpose of this paper is to examine the developmental strategies and perspectives of the British administration at an early stage of colonisation in Ceylon. The paper will fall into four categories:

1. A sketch of the Jurisprudence of the Kandyan Legal System.

2. Areas of conflict between the Common Law traditions of the early 19th Century and the Laws of the Kingdom of Kandy.

3. The modernising trend.

4. The new development.

8 Article 7.

9 Viz: the dismemberment of limbs and organs by elephants; crushing of heads by elephants; slow penetration of a spike through the body commencing from the anus; tearing a part of a human being and such unusually cruel punishments. See Vimalananda (T), op. cit., at pp. 65-66 for a particularly chilling episode of a punishment for treason. Where the miscreant escapes apprehension the family (wife and children) of the miscreant is put to death. The males by beheading. The females by drowning.

10 See Articles 5 and 8 of the Convention.

11 Hayley (F. A.), Sinhalese Larws and Customs, Cave \& Co. Ltd., Colombo, 1923, at pp., 533-535.

12 De Silva (K. M.), History of Ceylon, Vol. 3, University of Press Board, Colombo, 1973, at page 27. 


\section{A Sketch of the Jurisprudence of the Kandyan Legal Systems}

The jurisprudence of the Kandyan Legal System received some considerable exposition during the early days of British rule. Aside from Sir John D'oyly's ${ }^{\mathbf{1 3}}$ work on the Constitution of The Kandyan Kingdom ${ }^{14}$, Sawer's Digest of Kandyan Law ${ }^{15}$ and Armour's Notes on Kandyan Law ${ }^{16}$ became standard works on this subject. In 1880, two scholars, Le Mesurier and Panabokke, translated "The Nithiniganduwa". This was a compilation of the Laws of the Kandyan Kingdom by a French jurist made at the end of the 18th Century. Although this translation was the last of a series of works on the Kandyan Law to be published, it was written by a scholar working within the Kingdom and its substance from the stand point of actual research predates the aforementioned works. Although the judges, during the early days of British rule had these various sources to draw from, the early judges appear to have drawn their authorities only from Armour, for they realised that his work was founded on a series of decisions of the Judicial Commissioner's courts which effectively took over the task of settling disputes from the time of the transference of power to the British ${ }^{17}$. Although Armour was not a judge of the Board of Judicial Commissioners for Kandy, unlike Sawers who was one, Armour's writings on Kandyan Law received the highest respect among both the Bench and the Bar at the time ${ }^{\mathbf{1 8}}$. It must, however, be said, that the works of D'oyly and of "The Nithiniganduwa" stands out as being founded upon empirical research deserving the highest respect. This part of the paper is compiled with reference to all the aforementioned sources and in addition to Dolapihilla's recent work ${ }^{\mathbf{1 9}}$ on the last days of Sri Wickrama Rajasinghe.

In theory, at least, the concept of "Equality before the Law" was fundamental to the English Common Law tradition. The English jurists traditionally rely on Dicey ${ }^{20}$, to support that theme. The idea of "Equality before the Law" has recently been challenged and in some quarters has been rejected as a grossly unfair concept. The oponents of this concept have argued that a number of considerations precede the proceedings before a court where the equality principle comes into play, and therefore, it is said, that to apply the equality principle in isolation of the surrounding circumstances would both be unreal and would indeed be unfair. The relative economic strengths of the parties would be an important aspect which should influence the tribunal's attitude towards the dispute. The Marxist jurists take this argument further.

They suggest that counter Revolutionaries and anti-state activists should be judged differently from social deviants and recalcitrant labour. In sum the trend today is to make equality before the law more real than what is achieved by a mere application of a set of rules equally to those who manage to come before the court.

The jurisprudence of the Kandyan legal system fundamentally differed both from the "equality of Dicey" and the "equality of those who opposed Dicey". The Kandyan legal system projected an unequal legal system applying rules unequally to its inhabitants. The sys-

13 One of the British Civil Servants who was concerned with the aff airs of the Kandyan Kingdom from a veryearlystage. He acted as the chief translator to the British government at the signing of the Kandyan Convention. Subsequently, he became the first "British Residence of the New Territories".

14 "A Sketch of the Constitution of the Kandyan Kingdom", Tisara Publishers, Colombo, 1975 (Re-print).

15 Sawers (S), Digest of Kandyan Law, edited by Modder and A Few Memoranda and Notes on the Kandyan Laws of Inheritance, Marriage and Slavery . . . etc., 1826. These two works of Simon Sawers have been reproduced in later publications, particularly in Turner (L.J.B.)'s edition of D'oyly (1929) - See footnote 14 above.

16 Armour (J), Notes on Kandyan Law, Ceylon Miscellany, Colombo, 1842.

17 Dissanayake and de Soysa, Kandyan Law . . . etc., Dhramasamaya Press, Colombo, 1963 at pp. 14-15.

18 Ibid., at pp., 13-15.

19 Dolapihilla (P), In the days of Sri Wickrama Rajasinghe, Saman Press, Colombo, 1959.

20 Sommersett's Case (1771) 20 ST. 1 and Dicey (A. V.), Law of the Constitution, first edition, McMillan \& Co. Ltd., 1885. 
tem was based on Caste considerations plugged into a hierachical order of social grades. The social order within the Kandyan Kingdom was based on birth rights. Birth determines the Caste and the Caste determines both the individual's rights and his duties. These social grades were interlinked with a combination of "service and respect" in the ascending order and the extraction of those "services and respect" in the decending order. As a developmental model it projected the most primitive paradigm. To each social order was relegated a duty to perform a particular service to the community and it is within that service that the members of that social order was permitted to develop. Ability, aptitude and volens played no part in the selection. Birth alone determined the particular developmental role the individual was destined to play within the total concept of the State. Interpenetration of the various social orders was prevented by segregating each social order into designated areas. Social custom prevented inter-marriage or close social intercourse. The legal system took cognisance of these facts and merely concretized these pernicious social arrangements, by attaching severe penalties to attempts made at breaking them down. The role of law was, therefore, to maintain the social structure generated by the Kandyan society. The Law itself recognised a series of social conditions, extending from the untouchable - Rodiyas - to the Kandyan aristocracy from whom the King's ministers and governors were chosen. In between these two points in the social ladder, were arranged: the carpenters, the land tillers, the road sweepers, the drum beaters, the washer caste and a series of other castes. Each of these, including the Aristocracy were distinguished by the services they were each required to perform. The services of the Aristocracy was to rule als the Agents of the Monarch. The rest were required to serve others including the rulers with specified work. No amount of education, skill or wealth helped them to move into a different social or service niche. The law of the Kandyan Kingdom was designed to preserve this traditional social order. Under the Kandyan Convention and the protocols attached thereto, the British government accepted a binding obligation to preserve these laws and legal institutions.

The next section of this paper is to ascertain the various areas of conflict, between the raditions of the English Common Law and the Laws of the Kingdom of Kandy.

\section{Areas of Conflict Between the Common Law Traditions of the Early 19th Century and the Laws of the Kingdom of Kandy}

Much has been written ${ }^{21}$ of the Common Law traditions. Regularity and consistency in the application of the rules together with Procedural Correctness are some of the features of the machinery of Justice in the Common Law. Regularity and Consistency in the application of the rules have been considered as an aspect of the doctrine of "Equality before the Law". Procedural correctness is considered, sometimes, by itself, as an element in the observation of the "Rule of Law". In any event, these features were regarded as fundamental to the administration of Justice in the Common Law system.

The Kandyan legal system presented a weak foundation for procedural correctness. The settlement of disputes was essentially localised. It was firmly left in the hands of the Chiefs. Although the Chiefs' courts had customary procedures, the way that the Chiefs had conducted the administration of justice in their respective chiefdoms resembled ad-hoc tribunals. Fines were collected for the coffers of the Chiefs and imprisonment of ten broadened into what was

21 Holmes (O. W.), The Common Law, Keeton(G. W.), English Law - The Judicial Contribution, 1881, David \& Charles, England, 1974. 
technically known as "Rajakariya" or "Free Service to the State". In these circumstances the interest of the State and the personal interest of the Chief became indistinguishable. And "Rajakariya" therefore took the insidious form of legalised slavery.

Regularity and consistency were non-existing concepts in the administration of justice in the Kandyan Kingdom. Linked to status and caste considerations the legal system produced an internal value system which to a large extent determined the application of rules generally considered as law within the Kingdom. Notwithstanding the availability and the clarity of rules, their application, particularly at the local level, depended largely on the internal order of values. Such circumstances naturally makes the distinction between law and social values a difficult one to draw. Insofar as the Kandyan Kingdom was concerned the order of social velues took prominence superceding the law. The law, therefore, was both irregularly and inconsistently applied. The system in fact was open to corruption. The order of social values was indeed a system worked out for the maintenance of the rights and privileges of the Kandyan aristrocracy. Built into the hierachical composition of the caste system were manorial rights over what was called "Nindagam" land. Higher the caste, more extensive were the rights over immovable property gifted by the King. More politically powerful were the members of the aristrocracy, the more corrupt did they become. It is the aristrocracy that provided the judges for the Chief's courts. Individual interests, therefore, broadened into State interests - so long as the individual concerned did belong to the Kandyan aristocracy, but not otherwise.

Aside from this area of conflict, the Common Law and the Kandyan Law conflicted in another and an equally important area. That was on the issue of "quality of justice". Although aspects of judicial review and principles of civil liberties had not fully evolved within the English legal system by the early 19th Century, the English Common Law had, however, evolved a quality of justice which was in a sense the envy of Europe in the 19th Century ${ }^{22}$. During the early days of British administration, concern was expressed over the quality of Kandyan Justice. Despite the binding obligation ${ }^{23}$ assumed by the British government, to see that the rights of the Kandyan citizenry were preserved and protected under the customary law of the Kandyan Kingdom, they took the first opportunity to depart from that obligation.

The Advocate-Fiscal at the time argued that the Charter of Justice of $1801^{24}$ pre dated the Convention ${ }^{25}$ and therefore rendered the articles "which provided for the administration of justice for the Kandyans according to their own laws and institutions ... . illegal, and that every person in the newly acquired provinces, whether native or European, was subject to the criminal jurisdiction of the Supreme Court, and entitled to the privileges of a jury trial ${ }^{26}$. Although much dissatisfaction was expressed by a number of British administrators ${ }^{27}$ at the time, over the quality of justice provided by the Kandyan Chiefs, Governor Brownrigg hung on to the articles of the Convention until the Kandyan Rebellion of 1817-1818, almost two whole years after the signing of the Convention. Seizing the opportunity afforded by the Kandyan Rebellion of 1817, Brownrigg proceeded to re-structure the system of judicial ad-

\footnotetext{
22 Essays in Imperial Government Edt., Perham (M), Blackwell, Oxford, 1963 - "British Imperialism in the late 18th century: Defence or opulence?" at pp. 23-45.

23 Article 8 of the Convention.

24 Legislative Enactments of Ceylon, Vol. I (1796-1833), at p. 31. The Charter of Justice was in the form of a direction sent by Lord Dundas to Governor North in a dispatch dated 13th March 1801. See C. O. 55, 61. Also: De Silva (C. R.), Ceylon Under the British Occupation, 1795-1833, The Colombo Apothecaries, Co., Ltd., 1953, at pp. 314-317 and Nadaraja(T), The Legal System of Ceylon in its Historical Setting, Brill (E. J.), Leiden, 1972, pp. 59 et cetera.

25 Namely, the Kandyan Convention of 2nd March, 1815.

26 Kannangara, (P. D.); The History of the Ceylon Civil Service, 1802-1833, Tisara Press, Colombo, 1966, at p. 105.

27 De Silva (C. R.), op. cit., pp. 169-171 and Kannangara (P. D.), The History of the Ceylon Civil Service, 1802-1833, Tisara Prakasakayo, Colombo, 1966, pp. XXIX-XXXI.
} 
ministration in Kandy, notwithstanding the Articles. The British government argued that the participation of the Kandyan signatories to the Convention in the rebellion was an explicit breach of the Convention leaving the British government free to consider the Convention as at an end. This line of argument was never tested in a court of law. The result being the Proclamation of 21 st November, 1818, under which the British administration introduced a new system of government. Changes thus introduced to the system of government in the Kandyan provinces, were significant. A careful analysis of these changes suggest a radical departure from the plan for Kandyan development originally conceived by the British administration under the 1815 Convention. An attempt was made to break away from a traditional pattern of development tied to the social idio syncrasies of a traditional society and move towards establishing a paradigm of development capable of evolving a society espousing a theme of social justice based on social equality. Modernization thus introduced was firmly placed within a broad framework of civil rights and civil liberties according to the English Common Law. The skill of Governor Brownrigg and the British Colonial administration was displayed by making these changes work, while preserving certain rights and privileges guaranteed to the Chiefs under the Kandyan Convention. Titles, land rights and certain privileges were left unaffected, at least for a time until a stable infrastructure capable of supporting a modern system of judicial administration was constructed.

\section{The Modernising Trend}

The historical and political antecedents which led to the Rebellion of 1817-1818 has been well enumerated by a number of commentators ${ }^{28}$. Any reference to these events will fall outside the scope of this paper. It must, however, be mentioned, that the British administration as a historical and a political fact blamed their own failure to fill more securely into the shoes of the deposed monarch as a singular reason for making the rebellion possible. The Proclamation of 1818 was designed partly to remedy that lapse and partly to introduce into the Kandyan Provinces a modern system of administration underpinned by the institutions of the English Common Law. Of the 55 clauses in the Proclamation, Clauses 34-55 constituted a Charter of Justice. Clause 7, proclaimed: "that every Kandyan, be he of the highest or lowest class is secured in his life, liberty and property from encroachment of any kind or by any person, and is only subject to the laws, which will be administered according to the ancient and established usages of the Country, and in such manner and by such authorities and persons as in the name and on behalf of His Majesty as hereinafter declared". Clauses 34-55 and legislations subordinate thereto pulled the Kandyan legal system into line with the English Common Law. Among other changes, the abolishing of slavery ${ }^{29}$ and polygamy $y^{\mathbf{3 0}}$, and the introduction of the English law of Evidence ${ }^{31}$ were important subsidiary changes. By 1852, the stage was set for further advances towards modernization. By Ordinance No. 5 of that year, the Law of England was introduced into many areas which were previously the exclusive preserve of the Kandyan Law. By the same Ordinance an assimilation of the laws of the Kandyan provinces with those of the Maritime Provinces was initiated. This process of modernization left certain limited areas, ultimately, for determination under the traditional laws of the Kandyan Kingdom. These were:

\footnotetext{
28 Vimalananda (T): The Kandyan Rebellion, Gunasena \& Co., Ltd., Colombo, 1970.

29 Ordinance No. 20 of 1844.

30 Ordinance No. 13 of 1859 and Ordinance No. 3 of 1870.

31 Ordinance No. 3 of 1846.
} 
1. Marriage - subject to considerable modifications by local statutes.

2. Inheritance and succession.

3. The law relating to Adoption.

4. The rights of Acquisition.

Except in the four aforementioned areas, the Kandyan law was replaced by the English Common Law. This situation continued right up to the point of Independence in 1948. Aside from a revision ${ }^{32}$ of the Kandyan Law Declaration and Amendment Ordinance ${ }^{33}$, the Independent government of Ceylon made a changes in the ambit of the operation of the traditional law of Kandy. Both the Ordinance ${ }^{\mathbf{3 4}}$ and the Revision ${ }^{\mathbf{3 5}}$, charters the area made available for the Kandyan Law in an express manner. Part I of the Revision deals with "Transfer of Property". Part II deals with "Adoption" - Part III deals with "Marriage". Part IV and V deal with "Inheritance - Immovable Property" and "Inheritance - Movable Property", respectively. By section 1 (2), the application of this legislation has been limited "to persons subject to the Kandyan Law".

The crucial point in any litigation is one Kandyan Status. The question is this. Who is a Kandyan? In an early decision ${ }^{36}$ of the Supreme Court, it was held that "no person possessed the personal status of a Kandyan unless he could establish an unbroken Kandyan parentage on both sides up to the date of the the cession of the Kandyan Kingdom and that the estates of all persons who are the offspring of a mixed marriage between a Kandyan Sinhalese and a low country Sinhalese, or the descendants of such offspring must devolve in accordance with the Roman Dutch Law"37. Although this observation of the Supreme Court was well founded, the government decided by Ordinance No. 23 of 1917 to alter that definition and broaden it to include other categories of persons ${ }^{38}$. These changes became possible by the fact that the British government by clauses 9-15 of the Proclamation of 1818 had circumscribed and thereby limited the authority of the Kandyan Chiefs. Further, by limiting the authority of the Chiefs and making them totally subservient and sub-ordinate to the colonial power, the Proclamation was designed to undermine the influence of the Chiefs to a very significant extent. Describing the mode of appointment of Chiefs after the Proclamation, Dr. Colvin R. De Silva ${ }^{39}$ wrote:

"The mode of their appointment, from Adigar to petty headmen, was defined, and they were completely subordinate to the Kandyan Board and British Agents, without whose orders they were to have no power whatsoever to act $^{\mathbf{4 0}}$."

The work of the British administration, from 1818 appears to have been two fold. First by reorganising the mechanisms and modalities available for the due administration of justice within the Kandyan provinces, the British government with care and skill dismantled the existing infrastructure and replaced it with a new infrastructure capable of withstanding the dead weight of the changes which were being introduced, particularly, after the rebellion of 1818.

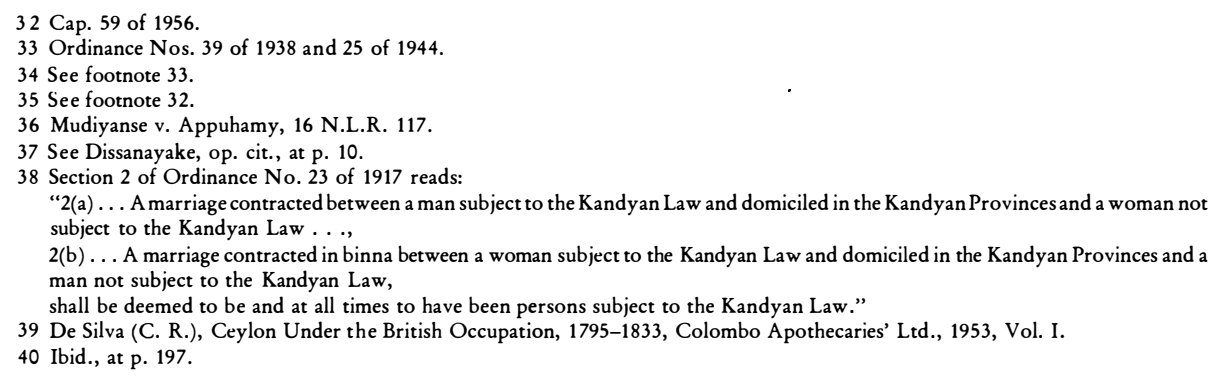


'The need for an institutional change was upper most in the colonial mind. Such a change was merely a prelude to a complete overhauling of the rules of the Kandyan legal system. This indeed was the second step. Once traditional institutions, which formed the infrastructure of the Kandyan legal system, were dismantled under the Proclamation of 1818 the stage was set for the restriction of the Kandyan laws and customs to particular areas, while leaving large areas of inter-personal disputes squarely within the ambit of the received law - namely, the English Common Law.

Towards achieving this end, the British government proceeded in stages to limit the area of application for the Kandyan law. This has been mentioned earlier. Hand in hand with this restricting process of the indigenous law, the British administration was determined to introduce a legal infra-structure to support the new law. They were, therefore able to see that the r.ew law was both effective and efficient. Once the old law and the monarchical infrastruccure were swept away, the colonial government felt secure in their thought that a new legal culture would now arise which would together with new legal traditions, to a large extent, act as a bulwark in support of British rule. In their minds this would effectively prevent the recurrence of rebellious behaviour among the Kandyan aristrocracy. They were indeed proved right in these assumptions. The modernization was therefore motivated by instincts of self preservation and propogation of colonial rule rather than as a part of a well organized developmental strategy. Nonetheless, its sociological impact among the Kandyan aristocracy was profound. And to this we must turn in the final segment of this paper.

\section{The New Developrent}

The geographical area occupied by the Kandyan Kingdom was vast and extensive. It occupied some of the richest lands of the Island. Although the Portuguese, before the Dutch, had made several unsuccessful attempts to conquer the Kandyan Kingdom, the Dutch and the British were contented with establishing firm trading ties with the Kings of Kandy. As Dr. Colvin R. de Silva ${ }^{\mathbf{4 1}}$ has observed, the British administrations of Sir Thomas Maitland ${ }^{\mathbf{4 2}}$ and Sir John Wilson ${ }^{43}$ were both firmly convinced that the interests of the British government would be best served by tapping the resources of the Kingdom by trade links rather than by conquest. However, the decision to conquer the Kandyan Kingdom was fortuitous and that decision eventually led to the assumption of the administration of Kandy under a Treaty - the Kandyan Convention. We have dealt with this aspect at an earlier stage of this paper. Bound by the Convention, the British government commenced their administration in 1815. They were obligated not only to enforce the traditional laws of Kandy, but also to uphold the traditional institutions of that Kingdom. The British administration of Governor Brownrigg followed these dictates assiduously until the Rebellion of 1817 . The proclamation of 1818 to which reference has been made earlier, could be considered as the beginning of a new developmental strategy conceived essentially for the Kandyan provinces, but its impact, as it will be seen later, was felt throughout the Island. The Proclamation, admittedly, introduced a new system of civil administration supported by new institutions for judicial administration. Associated with these was the reduction of the political powers of the Kandyan Chiefs. But the economic power they wealded as owners of "Nindagam property" remained

41 Ibid., at pp. 134-137.

42 Preceeded Governor Robert Brownrigg under whose governorship the annexation of Kandy took place.

43 Sir Thomas Maitland returned to England somewhat early, due to ill health. Sir John Wilson acted for Maitland until the arrival of Brownrigg on the Island. 
untrampelled. The Kandyan aristocracy continued to control vast tracts of the immensely rich terrain. The others who remained economically dependent upon them, still were, mere putty in their Chief's hands. Riddled with caste considerations and built in social biases underpinned by economic deprivations and traditional affiliations, the Kandyan aristocracy moved into the 20th Century with their local power base secure and intact. This scenario helped the British government enormously. The Agents of the British government were required to palliate the aristocracy; for, their loyalty, the government found, was sufficient to secure the loyalty of those who depended upon them. Aside from breaking this degenerate social configuration, the British government saw to it that the economic dependence of the Kandyan peasantry became institutionalised. This explains the Estate Labour question to which we shall turn later. As a parallel economic venture, the British government opened up former Royal lands for exploitation. The resulting plantation industry introduced both the Tea plant and the Rubber tree into the Kandyan provinces. These were run purely as an exploitative enterprise while the aristocracy hung on to "Nindagam land" which progressively slid back into a state of ineglect, disuse and waste resulting in arid economic stagnation. A classic programme for underdevelopment was thus inaugurated. Neither the British administration nor the governments of independent Sri Lanka were ill disposed towards "Nindagam" lands. Until the Land Reform Movement was launched"4 by the Bandaranaike government during the mid seventies of this century, the Kandyan aristocracy continued to benefit from the "Nindagams" originally established by the Kandyan Kings.

The emerging pattern for underdevelopment of the Kandyan peasantry was linked to the increase of profits for the foreign monopoly capitalists. The tea and rubber industries were limited to royal Lands which had been sold for a nominal price to companies registered in the United Kingdom. This commenced the era of Sterling companies. The Kandyan peasantry found themselves squeezed from both sides, once from the foreign monopoly capitalists and then from their own aristocracy. The opening of the plantations should have logically helped the development of the peasantry; but as events unfolded, this was not to be. The foreign investors were unaccustomed to caste and social divisions. Their experiences in the Carribean were with slave labour. They foind that slavery effectively dissolved tribal and regional ties. They were in no way ready to carry out the tasks of sociologists and thereby attempt at accommodating caste and social divisions. What the foreign investors needed was a labour force capable of carrying out the tasks of converting jungle land into plantations. They were, therefore, compelled to import labour from South India. The estate labour, thus constituted, were originally on contract. They were referred to as "indented labour". Their status differed from slavery by a hair's breath. Like the slaves, they were not free to leave. Unlike the slaves, they were not chattels in the ownership of any single person. The "indented persons" received an agreed remuneration, but they remained tied to their employers. As more plantations began to open, the Indian Indented Labour began to increase in numbers leaving nearly a million of their descendants behind, at the time of Independence, in 1948. That constituted $1 / 12$ of the total population of the Island at the time. By supporting legislations ${ }^{45}$ the British administration provided an infra-structure, capable of providing the institutions required for the effective implementation of the 'Indented Labour' programme, which indeed was a necessary element in the colonial development strategy for Ceylon. Some sociologist-

\footnotetext{
44 Land Reform Law No. 1 of 1972 as amended by Law No. 39 of 1975; ceiling on Housing Property Law No. 1 of 1973 as amended by Law No. 34 of 1974, by Law No. 18 of 1976 and by Law No. 19 of 1977. In support of the Land Reform Movement the Government enacted The Janawasa Law No. 25 of 1976. The Janawasas thus created, by section 2 of the Law functioned as Co-operatives charged with the duty of administering land thus acquired by the State under the Land Reform Movement. See sections 9 and 10 of Law No. 25 of 1976 .

45 See Ordinance Nos. 13 of 1889; 7 of 1890; 9 of 1909; 43 of 1921; 3 of 1914, 43 of 1921 and No. 1 of 1923.
} 
$s^{46}$ have ventured to suggest that cultural inhibitions among the Kandyan preasantry against working on foreign owned plantations, as an affront to their dignity, was perhaps in some way responsible for their reluctance to participate in the new openings afforded by the plantation industry. Major-General Hodgson, the Acting Governor ${ }^{\mathbf{4 7}}$ had blamed the basic instincts of idleness among the Sinhalese as a cause for their opting out of the new development plans for the colony. While laying emphasis on the caste configuration that existed among the Kandyan peasantry as a significant reason, other afflictions could well have subscribed to the failure of the plantation economy to draw in the Kandyan peasantry into the centre of their new developmental strategy for Ceylon.

This, however, makes the Indian Estate Labour population, an element in the developmental equation for Colonial Ceylon. Thus the plantation economy structured for Ceylon became wholly foreign based, making it a target for the nationalisation policies of a different millieu in the historical evolution of Ceylon. The exclusion of the Kandyan peasantry from participating in the development of the plantation industry of Ceylon has given rise to a number of socio-economic factors.

\section{First}

Notwithstanding the fact that Ceylon's colonial economy was sufficiently diversified so as to include - paddy, coconut and graphite - the tea and rubber plantation industries provided a major share towards strengthening its economic base. It provided nearly $70 \%$ of the earnings of colonial Ceylon. The fact that such a large share of the Island's economy lay exclusively in foreign hands tended to create a powerful political lobby in Westminster, in a way that the British government was persuaded to abandon certain progressive political policies formulated for Ceylon, when they appeared to collide with the economic interests of the monopoly capitalists in the United Kingdom with economic interests in the plantation industry in Ceylon.

The total absence of a trade union movement, the banning of political parties espousing the causes of the traditional labour movement and the failure of the British government to levy appriciable export duties and other forms of revenue collecting mechanisms against the sterling companies, resulted from this lobby.

\section{Second}

The exclusion of the Kandyan peasantry from the plantation industry created a large economically underdeveloped segment of the population, whose educational and social aspirations became, at least for the time being sub-ordinate to the Kandyan aristocracy. Together with the paucity of Christian missionary education in the Kandyan provinces, the peasant education of the Kandyan provinces became limited to whatever free Buddhist Nationalist education that was available to them in those provinces. The channels available to them were limited to schools sponsored by the Young Men's Buddhist

46 Although many sociologists have put forward the view that feelings of superiority and dignity had to a large extent prevented the Kandyan peasantry from participating in the plantation industry, no concrete proof of these has thus far being made available. See: Weerawardene (I.D.A.), The Revolt in the Temple, Sinha Publications, Colombo, 1953, pp. 108-115 and et cetera.

47 Major-General Hodgson - Officer Administrating the Government, in his address to the Legislative Council, on 19th August, 1868 reported in The Addresses delivered in the Legislative Council of Ceylon by Governors of the Colony, Vol. II, (1860-1877), Govt. Printer, Colombo, 1900. 
Association, the Buddhist Theosophical Society and to temple collegiates. The Buddhist Sinhala education, which was available to them, left them at a considerable disadvantage against the English educated aristocracy with easy access to Oxbridge and other British Universities.

Aside from the social disabilities built into the Caste system, the peasantry suffered twice, by their lack of recognised edcational qualifications.

\section{Third}

As decades upon decades began to evolve, since the early 19th Century, the Estate labour formed a new social element on the Kandyan scene. At the point of Independence, in 1948, almost 1/12 of the total population of Ceylon constituted Estate labour. As from the first independent government of Ceylon, plans were set to organise the repatriation of the Estate labour back to India. Finally, as a result of what is now known as the Bandaranaike - Shastri Pact of the Sixties, regulated ship loads of the Estate labour have been crossing the "Palk Straights" back into India.

With the repatiation of the Estate labour the Bandaranaike government has proceeded to nationalise ${ }^{48}$ the various sterling tea and rubber plantations on the Island. These have now become vested in public corporations falling within the mandate of the Minister of Plantation Industry. The government being the new owners have begun a "crash programme" to introduce the Kandyan peasantry into the Plantation Industry. It has, therefore, come a full circle. That which the British government was unable or unwilling to achieve at the beginning of their mandate in the early 19th Century, the Independent government of Mrs. Bandaranaike has now succeeded in achieving it in the mid-seventies of the present century.

Had the British administration integrated the Kandyan peasantry into their plantation industry, the path of their development could have taken a different turn. Several decades must now pass before one could assess the effect of the new change upon the socio-economic base of the Kandyan provinces. Until then it remains merely in the realms of conjecture to suggest as to what they may have lost by being excluded from the equation for Kandyan development worked out by the British administration at the middle of the 19th Century.

In the light of the foregoing the post independent policies for Kandyan development may be examined. Until the mid-seventies of this century the post independent administration of Ceylon made no attempt to integrate the Kandyan peasantry into the main stream of development. The lack of any coherent land reform movement deprived the peasants from obtaining any share in the control over land. The propogation of English as the official language, coupled with their exclusive knowledge of the vernacular-Sinhala, excluded them from the Civil Service and other government sources of employment. The absence of an English education barred them from every known profession, too. Under-development and non-development were their lot. The passage of the Official Language Act in 1956 coupled with the abolition of "Nindagam lands"49 and the Land Reform Movement of 1974-76"50 opened the door, perhaps for the first time, for Kandyan development. The Land Reform

48 Land Reform (Amendment) Law No. 39 of 1975.

49 Abolition of Fidei-Commissa and Entails (Amendment) Law, No. 13 of 1972.

50 See footnote 44 above. 
Movement and the abolition of "Nindagam land" broke the strangle hold which the aristocracy held over land in the Kandyan provinces. The limitation ${ }^{51}$ of land holdings to 50 acres per adult person forced the aristocracy to disgorge their land holdings. These were then available to the Land Reform Commission ${ }^{52}$ for distribution among the landless peasants. The adoption of Sinhala as the official language and its implementation by making Sinhala the medium of instruction in schools and in the universities of the Island opened the door to the Kandyan peasants for higher education. The result was indeed the introduction of the Kandyan peasants, together with the rest of the nation into an integrated programme for economic and social development. Although the language switch-over and the Land Reform Movement had a significance, generally for the whole nation, the abolition of "Nindagam land" had a particular significance to the Kandyan peasantry. For the first time ever, that made a large area of the land in the Kandyan provinces, available for distribution.

The new formula for socio-economic development of the former Kandyan Kingdom now rests upon a programme for social and economic integration. Although caste and creed differences are generally slow to disappear, the Bandaranaike government realised that the availability of economic opportunities was central to social integration. The Land Reform Movement coupled with the abolition of "Nindagan Land" and the programmes connected with the language switch-over from English to Sinhala were designed to equalise the available economic opportunities. It also provided the means for shifting the centre of traditional political and economic power from the hands of the descendants of the Kandyan Chiefs into the hands of the Kandyan masses. Bound by the Kandyan Convention ${ }^{53}$ of 1815 and the need to administer the country in the language of the Imperial power, the British government was unable to introduce the aforementioned centre pieces ${ }^{54}$ for reform and change.

51 Section 3, Land Reform Law No. 1 of 1972.

52 A Land Reform Commission was created by section 43 of Land Reform Law No. 1 of 1972. By section 43, the Commission was declared to be a body corporate, having perpetual succession and a common seal. Section 44 spelt out the powers of the Commission. These were:

(a) to acquire, hold, take or give on lease or hire, exchange, mortgage, pledge, sell or otherwise dispose of, any movable or immovable property;

(b) to carry out investigations, surveys and record data concerning . . . any agricultural land . . .

(c) to conduct assist and encourage research into all aspects of land tenure and reform,

and such other matters concerned with the effective administration of land acquired by the Commission. As land held in excess of the 50 acre limit enforced by section 3 of this Law. See S. 44(d)-(m).

53 The Kandyan Convention bound the British government into preserving the institutions, rights and privileges of the Kandyan Kingdom. These included the protection of Nindagam Property.

54 Namely, the abolition of Nindagam Property, the land reform movement and the language switch-over. 


\section{Conclusions}

The reaction between the Kandyan legal system and the English Common Law, during the latter half of the 19th Century gave rise to two significant results.

First: the more traditional concepts of caste and social postulates as independent imperatives in the administration of justice was swept aside, substituting in its place - an approximate equality - before the law, as an element in the 19th Century approach to justice under the English Common Law.

Second: as an end-product in the introduction of the Common Law tradition into the Kandyan Provinces, a trend towards the modernization of the Kandyan traditional society, appears to have commenced. Modernization of traditional societies alone is not the key to development. As this paper indicates, modernization of traditional societies is of ten a prelude to greater economic exploitation. Modernization should proceed towards social and economic integration of the whole society into a single co hesive mass. The legal system should be used towards achieving this goal. Modernization which moves a traditional society towards this kind of harmonisation aids development. Modernization which introduces the instrumentalities for the institutionalisation of social and economic differences impedes development. 


\title{
Kandyan Law and British Colonial Law: A Conflict of Tradition and Modernity - An Early Stage of Colonial Development in Sri Lanka
}

\author{
By M. L. MARASINGHE
}

The article is intended to consider the problems of association between two types of legal systems based upon very different assumptions. The conquest of the Kandyan Kingdom brought about the acquisition of a sizeable land mass by the British, in Ceylon, inheriting a legal system based on certain Ethno-social and Religio-Cultural assumptions. The task of the British government was essentially one of reconciling some of the fundamental assumptions of the English Common Law with those of the Kandyan Law. The inequality in the application of the rules of law, the recognition of social stratification upon caste lines, the legalisation of torture and the recognition of Buddhism as the only lawful faith in the kingdom were some of the fundamental characteristics of the law and its institutions. The way by which the British government succeeded in assimilating such a system results in the modernization of a whole system of laws and institutions of a traditional legal system. This naturally creates a number of difficult socio-political problems. The article forms a part of a book on Law and Modernization in Sri Lanka which is presently been written by the author.

\section{Use and Abuse of the "Modern" versus "Traditional" Law-Dichotomy in South Africa}

\section{By SANDra Burman}

This paper discusses whether it is useful to categorise multi-cultural societies as either traditional or modern, with specific reference to the South African situation where this categorisation has been used for over a century. The distortions it introduces in the approach of legal officers to indigenous legal systems, and the difficulties it has led to in South Africa in acknowledging changing customs are examined in relation to current anthropological debates and court cases. Its role in enabling South Africa's policy makers to achieve certain policy goals is then analysed in an historical framework, and the paper concludes with a discussion of whether the dichotomy might be useful in predicting the course of future legal development in South Africa were the African population to have greater control of their legal system.

\section{Unité du Droit ou Diversité du Droit}

\section{By E. A. B. van Rouveroy van Nieuwaal}

The most complex questions for the African legislator are still the problems of adaptation, reform and integration of different laws into one national law system. These problems vary from country to country, from region to region even, due to a different social and economic development, but nearly always in a very fast way. They are increased by the colonial inheritance of diversity of law and culture. Most African governments decided after the Indepen- 